\title{
Oil price shocks and stock market returns: New evidence from the United States and China.
}

\author{
David C. Broadstock ${ }^{a}$ \& George Filis ${ }^{b}$
}

\begin{abstract}
${ }^{a}$ Research Institute of Economics and Management (RIEM), Southwestern University of Finance and Economics (SWUFE), 55 Guanghua Cun Jie, Chengdu, Sichuan, China, 6100074, and Surrey Energy Economics Centre (SEEC), Faculty of Economics Business and Law, University of Surrey, UK.

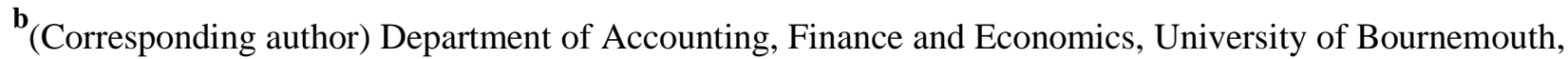
The Executive Business Centre, 89 Holdenhurst Road, Bournemouth, BH8 8EB UK, email: gfilis@ bournemouth.ac.uk, tel: 0044 (0) 1202 968739, fax: 0044 (0) 1202968833.
\end{abstract}

\begin{abstract}
This study examines the time-varying correlations between oil prices shocks of different types (supply-side, aggregate demand and oil-market specific demand as per Kilian (2009) who highlighted that "Not all oil shocks are alike") and stock market returns, using a Scalar-BEKK model. For this study we consider the aggregate stock market indices from two countries, China and the US, reflecting the most important developing and developed financial markets in the world. In addition to the whole market, we also consider correlations from key selected industrial sectors, namely Metals \& Mining, Oil \& Gas, Retail, Technology and Banking. The sample period runs from 1995 until 2013. We highlight several key points: (i) correlations between oil price shocks and stock returns are clearly and systematically time-varying; (ii) oil shocks of different types show substantial variation in their impact upon stock market returns; (iii) these effects differ widely across industrial sectors; and finally (iv) China is seemingly more resilient to oil price shocks than the US.
\end{abstract}

JEL Classifications: C32, G12, G14, Q4

Key words: Oil price shocks, Time-varying correlation, Chinese stock market, US stock market, Industrial sectors, Scalar-BEKK 


\section{Introduction and brief review of the literature}

In this paper we extend the works of Kilian (2009) and Kilian and Park (2009) by examining how the financial returns of the aggregate stock market and of key industrial sectors co-vary with different types of oil price shocks, and how this co-variance has strengthened (or weakened) over time. In particular, dynamic conditional correlations are evaluated using the Scalar-BEKK model proposed by Engle and Kroner (1995) to examine the aforementioned time-varying relationship.

The pioneer in the study of oil prices and macroeconomic indicators was Hamilton (1983). Since then a vast amount of studies have been published and the majority of them voice the opinion that oil prices exert a significant impact on economic variables (some influential papers include, inter alia, Baumeister and Peersman, 2012; Lippi and Nobili, 2012; Segal, 2011; Rahman and Serletis, 2011; Tang et al., 2010; Jbir and Zouari-Ghorbel, 2009; Nakov and Pescatori, 2009; Blanchard and Gali, 2007; Hamilton, 2008, 1996; Hamilton and Herrera, 2004; Barsky and Kilian, 2004; Jones et al., 2004; Leduc and Sill, 2004; Brown and Yucel, 2002; Hooker, 2002, 1996; Amano and van Norden, 1998; Bernanke et al., 1997; Rotemberg and Woodford, 1996; Huang et al., 1996; Darrat et al., 1996; Mork et al., 1994; Hutchison, 1993; Mork, 1989; and Burbidge and Harrison, 1984). Despite the fact that the oil literature dates back into the early 80s, the relationship between oil prices and stock markets has received a marked increase in attention by researchers only over the last two decades ${ }^{1}$. The picture that is painted by these studies advocates in favour of a negative relationship between oil price changes and stock market performance (see, inter alia, Asteriou and Bashmakova, 2013; Filis and Chatziantoniou, 2013; Ciner, 2013; Lee and Chiou, 2011; Laopodis, 2011; Filis, 2010; Chen, 2009; Miller and Ratti, 2009; Driesprong et al., 2008; Nandha and Faff, 2008; O'Neill et al., 2008; Park and Ratti, 2008; Bachmeier, 2008; Henriques and Sadorsky, 2008; Sadorsky, 2001; Papapetrou, 2001; Ciner, 2001; Gjerde and Sættem, 1999; Huang et al., 1996; Jones and Kaul, 1996).

Furthermore, the literature had remained generally silent until very recently regarding the effects of oil prices on the stock market industrial sectors. Some interesting studies include those by Degiannakis et al. (2013), Scholtens and Yurtsever (2012), Arouri (2012), Broadstock et al. (2012), Narayan and Sharma (2011), Arouri (2011), Elyasiani et al. (2011), Mohanty et al.

\footnotetext{
${ }^{1}$ It is not immediately clear why this surge of study has been within the past decade or so, but several points may contribute: first the availability of daily data online through numerous web portals has been massively improved; second the methods for handling volatile data were not 'mainstream' until recent years; and third the sheer volume of papers being published has risen dramatically in the last few years (particularly in some leading energy related journals), generating a sheer scale effect.
} 
(2011), Arouri et al. (2011), Arouri and Nguyen (2010), Kilian and Park (2009), Nandha and Faff (2008), Boyer and Filion (2007), El-Sharif et al. (2005) and Hammoudeh and Li (2005). The general consensus from these studies is that the Oil \& Gas sector, and also the Mining sector, tends to be positively affected by positive changes in oil prices, whereas the reverse holds true for other sectors, such as Transportation, Manufacturing, Food, Chemicals, Medical, Computer, Real Estate and General Services. Inconclusive results are reported for the Electricity, Engineering and Financial sectors. Thus, overall it could be suggested that there is a positive effect of the oil prices on oil-related and oil-substitute sectors, a negative effect on oil-using sectors and not a significant effect on non-oil-related sectors (such as the financial sector) ${ }^{2}$.

Following Hamilton (2009a,b) and Kilian (2008a,b, 2009), we also subscribe to the belief that we cannot paint a complete picture on the relationship between oil prices and the economy or the financial markets, unless we separate the origins of the oil price shocks. These authors were the first to distinguish between supply-side and demand-side oil price shocks, arguing that these shocks would trigger different responses from the economic indicators and financial markets. We should add here that Kilian (2009) disentangles further the demand-side oil price shocks into aggregate demand shocks and precautionary demand shocks (or oil-market specific demand shocks) in an effort to capture the oil price shocks that originate from an increase in world aggregate demand and those that originate from the increased demand due to uncertainty about the future availability of oil, respectively. Pertaining to the readily available information, a positive relationship has been established between aggregate demand shocks and economic and/or stock market developments, whereas a negative relationship holds during oil-market specific demand shocks. At this point it is worth noting that at the other end of the spectrum, there is a growing body of literature shaping around the concept that supply-side oil price shocks do not exercise any effects anymore on either the economy or the financial markets (see, inter alia, Degiannakis et al., 2014; Abhyankar et al., 2013; Kang and Ratti, 2013; Baumeister and Peersman, 2012; Basher et al., 2012; Lippi and Nobili, 2012; Kilian and Lewis, 2011; Kilian and Park, 2009; Hamilton, 2009a,b; Kilian, 2009; Apergis and Miller, 2009; Lescaroux and Mignon, 2008; Kilian, 2008a,b; and Barsky and Kilian, 2004). Nevertheless, Chen et al. (2014) focus on

\footnotetext{
${ }^{2}$ Gogineni (2010) offers compelling justification and logic behind these general findings noting that supply chain dependency (and hence exposure) to oil markets is key to determining the relevance of oil price changes in any given sector.
} 
France, Germany, Japan, the UK and the US and report that supply side shocks exercise a more persistent effect on stock prices.

The aforementioned studies, though, have largely ignored the importance of examining the relationship between oil prices and stock markets in a time-varying environment. Time-varying correlation models have only very recently been applied to investigate oil and stock market relationships. Some notable studies include for instance Choi and Hammoudeh (2010) who apply the Dynamic Conditional Correlation model (DCC) to investigate relationships between commodity prices including oil, copper, gold and silver, with the S\&P 500 index and show evidence of increasing correlations between all commodities since 2003 but decreasing correlations with the stock index. Similarly, Chang et al. (2010) show that in the US, conditional correlations between crude oil prices and stock returns are not constant. Filis et al. (2011) go further and separate oil importing from exporting countries in their analysis and, using a DCC generalized autoregressive conditionally heteroskedastic (DCC-GARCH) specification, show that during oil-market specific demand shocks a negative relationship between oil and stock market returns exists, whereas a positive correlation was observed during aggregate demand shocks. More recently, Broadstock et al. (2012) use a BEKK model to identify the time-varying relationship between oil prices and energy related stocks in China, identifying a sharp increase in correlation during the 2008 financial crisis, while Antonakakis and Filis (2013) examine the time-varying effects of oil prices changes on stock market correlation, using a DCC-GARCH model.

This paper links two strands of the literature (oil-price shocks and time-varying correlation between oil price and stock market returns) in an effort to reveal some rather important findings which have not been reported previously. Overall, the innovations of this paper can be described succinctly as follows. First, we disentangle oil prices into specific shock series using Kilian's (2009) framework, namely supply, aggregate demand and oil-market specific demand based shocks. Using these, we examine the time-varying relationship between each of the three shocks and stock market returns. Second, we examine the said relationship for both aggregate stock market indices and selected industrial sector indices. Finally, we examine this relationship in the most important developed (US) and developing (China) stock markets in the world, using a Scalar-BEKK model. As Broadstock et al. (2012) argue, despite the fact that China represents the second largest economy in the world and that the Chinese stock market is the second largest 
stock market in the world, there is not an extensive literature examining the relationship between oil price and stock market behaviour in China.

Our main findings can be summarised as follows: (i) correlations between oil price shocks and stock returns are clearly and systematically time-varying; (ii) oil shocks of different types show substantial variation in their impact upon stock market returns; (iii) these effects differ widely between industry sectors; and finally (iv) China is seemingly more resilient to oil price shocks than the US. These findings have important implications for both practitioners and policy makers. To illustrate this we discuss how time-varying correlations could be utilised in financial investments, why these correlations differ so greatly across industries and economies and what would be the more immediate financial consequences.

The rest of the paper is organised as follows: Section 2 describes the methodology and data used in the study, Section 3 presents the empirical findings and Section 4 concludes the study.

\section{Methodology}

In light of the issues discussed in Section 1, the aim is to apply a methodology that achieves several goals. First is to model the (endogenous) relationships between oil production, economic activity and oil price changes, allowing for some pre-determined structural relationships in the modelling framework. Second, and given the output from the first part, we identify the oil price shocks of different types (i.e. supply-side and demand-side). Third, using the derived oil price shock series, we establish how sensitive aggregate stock market indices and industry specific portfolios are to these shocks, and additionally consider whether such sensitivities are evolving over time.

\subsection{Structural VAR model and historical price decomposition}

Following Kilian (2009), our analysis begins by modelling the endogenous relationships between the estimation variables using a structural vector autoregression (SVAR) model of the form:

$$
\mathbf{A}_{0} \mathbf{z}_{t}=\mathbf{a}_{0}+\sum_{i=1}^{p} \mathbf{A}_{i} \mathbf{z}_{t-i}+\boldsymbol{\varepsilon}_{t}
$$

where, $\mathbf{z}_{t}$ is a $[3 \times 1]$ vector of endogenous variables containing world oil production, the global economic activity index and real oil price returns, noting that the order of the variables is important. Kilian (2009) uses price levels instead of returns; the reason for us using returns here 
is because of our desire to establish correlation with stock market returns. In Equation (1) $\mathbf{A}_{0}$ represents the [3x3] contemporaneous matrix used to identify the structural relationships, $\mathbf{A}_{i}$ are [3x3] autoregressive coefficient matrices, $\boldsymbol{\varepsilon}_{\mathrm{t}}$ is a [3×1] vector of structural disturbances, assumed to be serially uncorrelated and $p$ denotes the order of the SVAR model which is set equal to 24 months. The covariance matrix of the structural disturbances takes the following form:

$$
E\left[\boldsymbol{\varepsilon}_{t} \boldsymbol{\varepsilon}_{t}\right]=\mathbf{D}=\left[\begin{array}{ccc}
\sigma_{1}^{2} & 0 & 0 \\
0 & \sigma_{2}^{2} & 0 \\
0 & 0 & \sigma_{3}^{2}
\end{array}\right]
$$

That is to say, there are no cross-equation co-variances in the residuals. Estimation of the SVAR is often done using a reduced form VAR obtained by multiplying both sides of Equation (1) with $\mathbf{A}_{0}^{-1}:$

$$
\mathbf{z}_{t}=\mathbf{c}_{0}+\sum_{i=1}^{p} \mathbf{B}_{i} \mathbf{z}_{t-i}+\mathbf{e}_{t}
$$

where, $\mathbf{c}_{0}=\mathbf{A}_{0}^{-1} \mathbf{a}_{0}, \mathbf{B}_{i}=\mathbf{A}_{0}^{-1} \mathbf{A}_{i}$, and $\mathbf{e}_{t}=\mathbf{A}_{0}^{-1} \boldsymbol{\varepsilon}_{t}$.

The reduced form errors $\mathbf{e}_{t}$ are therefore linear combinations of the structural errors $\boldsymbol{\varepsilon}_{t}$, with a covariance matrix of the form $E\left[\mathbf{e}_{t} \mathbf{e}_{t}^{\prime}\right]=\mathbf{A}_{0}^{-1} \mathbf{D} \mathbf{A}_{0}^{-1^{\prime}}$. The structural disturbances can then be derived by imposing suitable restrictions on $\mathbf{A}_{0}^{-1}$. Here, following Kilian (2009), the restrictions are identified based on macroeconomic priors rather than an empirical identification scheme ${ }^{3}$. Specifically, the following block-recursive short-run restrictions are used:

$$
\left(\begin{array}{c}
e_{1, t}^{\Delta \text { globaloilproduction }} \\
e_{2, t}^{\text {globalreal activity }} \\
e_{3, t}^{\text {real oilprice returns }}
\end{array}\right)=\left[\begin{array}{ccc}
a_{11} & 0 & 0 \\
a_{21} & a_{22} & 0 \\
a_{31} & a_{32} & a_{33}
\end{array}\right]\left(\begin{array}{c}
\varepsilon_{1, t}^{\text {oilsupplyshock }} \\
\varepsilon_{2, t}^{\text {aggregatedemand shock }} \\
\varepsilon_{3, t}^{\text {oil-market specific demand shock }}
\end{array}\right)
$$

Thus, oil supply shocks are only due to innovations in oil production. Aggregate demand shocks can be come from one of two sources, namely real activity specific shocks, but also from shocks

\footnotetext{
${ }^{3}$ Granger causality tests and Directed Acyclic Graphs are two common empirical identification schemes used in SVAR applications. See for example Swanson and Granger (1997) or more recently Mjelde and Bessler (2009).
} 
to global oil production. Finally, the structural oil-market specific demand shocks are not only due to unexpected oil price changes, but also unexpected disruptions to the production process and sudden, and unpredictable, shifts in global economic activity.

These identifying restrictions are motivated as follows: (1) crude oil supply will not respond to oil demand shocks within the month, given the costs of adjusting oil production and the uncertainty about the state of the crude oil market; (2) increases in the real price of oil driven by shocks that are specific to the oil market will not lower global real economic activity within the month, given the sluggishness of global real activity; and (3) innovations to the real price of oil that cannot be explained by oil supply shocks or shocks to the aggregate demand for industrial commodities must be demand shocks that are specific to the oil market.

The estimation of the SVAR model in Equation (1) allows us to proceed to the historical decomposition on the oil price return series. Kilian and Park (2009) suggest that the decomposition can be done by "simulating the path of the real price of oil from [the estimated SVAR model] under the counterfactual assumption that a given shock is zero throughout the sample period. The difference between this counterfactual path and the actual path of the real price of oil measures the cumulative effect of the shock at each point in time." (page 1272, footnote 6). Accordingly, in the present paper, we decompose the real oil price return series, as follows:

- Oil supply shocks: by setting the oil supply innovations to zero for all periods, then calculating the counterfactual values of real oil price returns and recording them.

- Aggregate oil demand shocks: by setting the global economic activity innovations to zero for all periods, then calculating the counterfactual values of real oil price returns and recording them.

- Oil-market specific demand shocks: by setting the oil price innovations to zero for all periods, then calculating the counterfactual values of real oil price returns and recording them.

These shocks are effectively an identity decomposition of the reduced form innovations into their structural components, and in this regard, by definition the three series must sum up to the reduced form innovations for the oil price equation. It is of course possible to extract other shock series from the model, such as the two shocks that affect global economic activity, but as these are not used here we do not discuss them further. 
The derived shock series are "global", in the sense that they are derived using measures of global oil production, global economic activity and global oil prices. Therefore the same shocks are used for both China and the US. This is further justified by acknowledging that China and the US are two of the largest oil importers in the world.

\subsection{Estimating dynamic correlations in the presence of conditional heteroskedasticity}

To understand how oil shocks of different types affect stock markets and their constituent industry sectors, the dynamic correlations between these series are estimated. Several aspects must be considered within estimation. The dynamic correlations must be conditional on all of the available information in order to accurately describe the evolution of correlation, and not for instance simply characterize discrete differences across two (or more) pre-defined sample windows. Additionally, given the frequency of the observed data (which are monthly as described in Section 3), auto-regressive heteroskedasticity may be a further concern (GARCH). One candidate method often used to describe conditional correlations in the presence of GARCH is that of Engle (2002) who proposed the dynamic conditional correlation method (DCC) as a means to describe the time varying nature of correlations among variables conditional upon historically observed relationships.

Recently, though, Caporin and McAleer $(2008,2011)$ have argued that the BEKK of Baba, Engle, Kraft and Kroner (1991, working paper) and Engle and Kroner (1995) may be superior to DCC both theoretically and empirically. More specifically they argue that the Engle (2002) DCC does not strictly formulate a dynamic conditional correlation. Therefore, here we apply BEKK rather than DCC. The standard BEKK model requires the estimation of $(n(n+1) / 2)+2 n^{2}$ parameters, thus a less general version is commonly applied, named the Scalar-BEKK model. One advantage of this is that the Scalar-BEKK model is guaranteed to be positive definite and requires the estimation of fewer parameters than the BEKK model, i.e. $(n(n+1) / 2)+2$ parameters. In this present case this is advantageous since our data are monthly frequency only, and the number of observations (and hence degrees of freedom available for estimation) is relatively smaller than compared with higher frequency data.

The DCC of Engle (2002) directly estimates the correlation matrix, BEKK on the other hand evaluates the correlations indirectly. In this method, the data in $\mathbf{Y}_{t}$, reflect a multivariate vector 
containing market/portfolio returns $r_{t}$ and the oil price shocks contained in $\boldsymbol{\varepsilon}_{t}$, are assumed to follow a conditionally normal distribution:

$$
\mathbf{Y}_{t} \mid \mathbf{\Omega}_{t-1} \sim N\left(0, \mathbf{H}_{t}\right)
$$

In which $\boldsymbol{\Omega}_{t-1}$ is the information set at time $t-1$, and assuming a first order GARCH process:

$$
\mathbf{H}_{t}=\mathbf{C C}^{\prime}+\mathbf{A} \boldsymbol{\Sigma}_{t-1} \mathbf{A}^{\prime}+\mathbf{B} \mathbf{H}_{t-1} \mathbf{B}^{\prime}
$$

For the scalar representation, the assumption is that $\mathbf{A}$ and $\mathbf{B}$ are linearly related by a scaling factor i.e. $\mathbf{B}=\boldsymbol{\delta A}$, see for example Silvennoinen and Terasvirta (2009) for further discussion of the scalar BEKK and other multivariate GARCH methods. Given the estimated time-varying variances in $\mathbf{H}_{t}$, the time-varying correlations between two variables $i$ and $j$ in the system are then constructed using the relationship:

$$
\rho_{t}=\frac{\mathbf{h}_{i j t}}{\sqrt{\mathbf{h}_{i i t}} \sqrt{\mathbf{h}_{j j t}}}
$$

That is to say, in the case of BEKK, the time varying correlations are derived from the estimated model, whereas for DCC they are directly estimated. Additional useful discussion on the relationships between DCC and BEKK functional forms can also be found in Ding and Engle (2001), notwithstanding the important discussions already alluded to in Caporin and McAleer (2008, 2011) among others.

\section{Data Description}

In this study we use monthly data starting from January 1995 through to July 2013 on aggregate US and Chinese stock market indices (NYSE and Shanghai Composite index, respectively) and also on selected industrial sector indices from both countries (Banks, Metals \& Mining, Oil \& Gas, Retail and Technology). The choice of these indices was partly motivated by Kilian and Park (2009) and based on the fact that they reflect the main components of an economy. These data have been extracted from Datastream ${ }^{\circledR}$ for the US and the Chinese Stock Market and Accounting and Research database (CSMAR) for China ${ }^{4}$.

\footnotetext{
${ }^{4}$ The industry classifications for the Chinese firms are less clear/consistent than for firms in the US. Portfolio values are constructed manually from the firm level data using the following classifiers: Retail: H01, H11, H1120, H1199 Metal \& mining: B01, B0101, B05, B0501, B07, B0701, B0740, C65, C6510, C67, C69, C6901, C6935, Banks: I01, Oil \& Gas: B03, B5003, C41, Technology: C51, C 5110, C 5115, C55, G, G81, G8101, G8115, G83, G8310, G85, G8599, G87, G8701, G8799.
} 
In addition, monthly data have been collected January 1990 through to July 2013 for world oil production (OILPROD), oil prices (OILP) and global economic activity (GEA) index, which are used for the estimation of the oil price shocks, as discussed in Section 2.1 ${ }^{5}$. World oil prices are approximated by Brent crude oil, considering that this type of oil represents $60 \%$ of the world oil daily consumption (Maghyereh, 2004). The world oil production data serve as a proxy for world oil supply. The data for the Brent crude oil price and world oil production have been extracted from the Energy Information Administration, whereas the global economic activity index has been borrowed from Kilian's (2009) paper, and is based on dry cargo freight rates ${ }^{6}$. The period of the study is motivated by the availability of the Chinese data, as well as, the data on global economic activity index and the fact that we required a common sample period for the two countries. Prices are expressed in real dollar terms and are transformed into log-returns. Figure 1 exhibits the evolution of the series during the common sample period.

[FIGURE 1 HERE]

The effect of the 2007/09 global financial crisis is evident in Figure 1, where stock market returns (aggregate and industrial sectors) exhibited a significant higher volatility and negative returns. In addition, the global economic activity index suffered a significant drop during the same period of time, suggestive of the global economic downturn of that time. Similar patterns are observed in the oil price returns and changes in oil production.

Furthermore, Table 1 presents some descriptive statistics for the series under investigation. From Table 1 we observe that Chinese aggregate stock market returns, as well as, industrial sectors' returns exhibit a significantly higher volatility compared to the US market. Nevertheless, the highest volatility is observed in the global economic activity index. All US stock returns show a negative skewness indicating that there is a longer tail on the left side of the probability density function and the bulk of the returns are found to the right of the mean returns. The reverse is observed for the Chinese stock returns, with the exception the Shanghai index returns. Furthermore, almost all series are leptokurtic, with the only exception being the GEA. Finally, none of the returns (apart from the Chinese retail and technology industrial indices) are normally distributed, as indicated by the Jarque-Bera statistic.

\footnotetext{
${ }^{5}$ These data start earlier than the financial market data since the VAR model requires at least 24 months additional data for all of the lag terms. This allows us to produce historical decompositions that cover the whole of the observed financial market data.

${ }^{6}$ The data, which now cover a longer time-series than in the 2009 paper, can be found in Lutz Kilian personal website (http://www-personal.umich.edu/ lkilian/).
} 


\section{[TABLE 1 HERE]}

\section{Empirical Findings}

This section presents and discusses the results. Firstly the historical oil price change decomposition from the estimated SVAR is given. The second and main part of this section then concentrates on the analysis of the time-varying correlation between the three oil price shocks and stock market returns of China and the US (aggregate and industrial sectors returns).

\subsection{Oil shocks of different types (estimated historical decompositions).}

Figure 2 exhibits the cumulative effect of the three oil price shocks on oil price returns. The main effects are observed primarily from oil-market specific demand shocks and then from aggregate demand shocks. We can also notice that during the 2007/09 global financial crisis, aggregate demand shocks had a significant negative effect on oil prices. It can be seen that the contributions of oil shocks to oil price returns are generally mean reverting in the sense that they do not persist a clear trend. This is a marked difference from the contributions given in Kilian (2009), but is readily explained by the use here of oil price returns rather than prices in levels. The contribution of supply side shocks to price returns is generally notional comparing with aggregate and oil-market specific demand shocks.

[FIGURE 2 HERE]

The interesting question, though, is how these shocks are affecting stock market returns over time. Thus, in the next section we proceed with the analysis of the time-varying correlation between the three oil price shocks and stock market returns from China and the US.

\subsection{Time-varying correlations.}

\subsubsection{Aggregate stock market indices}

We start our analysis with the time-varying correlations ${ }^{7}$ (see Figure 3 ) between the three oil price shocks and aggregate stock market returns (i.e. the Shanghai Composite index and the NYSE index). Recalling from Section 1 we would expect aggregate demand shocks to exhibit mainly positive correlation with stock market returns on the premise that these shocks are driven by the global economic activity. Thus, higher economic activity should drive stock prices up,

\footnotetext{
${ }^{7}$ For sake of brevity the Scalar-BEKK results are not presented here but they are available upon request.
} 
while at the same time it increases the price of oil. The reverse should hold for oil-market specific demand shocks. These shocks generate uncertainty in the market, driving oil prices to higher levels, while at the same time stock prices down. Supply-side shocks are expected to show low or zero correlation with stock market returns considering that current evidence suggests these shocks do not currently exercise any important impact in the economy.

\section{[FIGURE 3 HERE]}

A preliminary visual assessment of the time-varying correlations in Figure 3 allows us to note some interesting features. Primarily we can observe that correlations do not remain constant but instead they vary over time. This finding reinforces our conjecture that the relationship between stock markets and oil price shocks should not be examined in a purely static environment. Furthermore, almost all correlations fluctuate between both positive and negative regions. This is suggestive of the fact that stock market returns tend to exhibit a fundamentally different relationship with oil price shocks during different time periods, and not just a marginally different one. In addition, correlations seem to have a higher magnitude for the NYSE index as compared to the Shanghai Composite index, for most of the period under examination, implying that the US market is more responsive to oil price shocks. Nevertheless, during turbulent periods, such as the early 2000 recession and the Great Recession of 2007/09, both stock markets exhibit similar magnitude. Overall, though, this finding implies that the Chinese stock market is relatively more 'secure' against oil market based risk. This latter finding is also in line with Nguyen and Bhatti (2012) who report that the Chinese stock market is not affected by oil prices during the period 2000-2009.

Turning the focus now on the NYSE index, the evidence suggests that the highest level of correlation is found with the aggregate demand shocks for the largest part of our sample. In addition, this correlation is always positive, as expected. The next highest correlation is found between NYSE index returns and oil-market specific demand shocks. Oil-market specific demand shocks tend to show a moderate positive correlation throughout the sample period, with the exception of the period 2003-2005. In addition, during the Great Recession of 2007/09 we observe a considerable increase in the positive correlation.

The finding that oil-market specific demand shocks are positively correlated with stock market returns during recessions seems counter-intuitive, given that past findings suggest a negative relationship. However a quick look at the data (in Figures 1 and 2) serves as a reminder that 
particularly the Great Recession period bared witness to an unprecedented and sustained fall in oil prices, a significant decrease of oil-market specific demand shocks, as well as, the collapse of the financial markets i.e. a clear and strong co-movement in the same direction.

Another plausible explanation of this positive correlation between the oil-market specific shocks and stock market returns can be found in the fact that apart from the uncertainty about the future availability of oil, there is evidence that financial speculation in the oil market has also been driving oil-market specific shocks (Kilian and Lee, 2014; Kilian and Murphy, 2014). A number of authors claim that the increased speculation the oil market, due to the increased participation of hedge funds, has created an increased correlation between oil prices and stock returns (Fattouh et al., 2013; Hamilton and Wu, 2012; Tang and Xiong, 2012; Buyuksahin and Robe, 2011; Alquist and Kilian, 2010; Buyuksahin et al., 2010; Silvennoinen and Thorp, 2010). Thus, such financialisation of the oil market could justify the positive correlation between the stock market returns and the oil-market specific shocks.

Supply-side shocks do not show a high correlation with stock market returns. In addition, this correlation is mainly low and negative with the exception the periods between mid-2000-2004 and 2012-2013.

It is worth noting that there is a divergence between the time-varying correlation of aggregate demand shocks and oil-specific demand shocks with the US stock returns over 2003-2006 and 2012-2013. However, there is not such divergence during other periods, such as the global financial crisis. A plausible explanation of this fact can be the following.

The period 2003-2006 is characterised by an upward movement of the global economy, as depicted by the Global Economic Activity index in Figure 1, as well as, a bullish period of the US stock market. Thus, on one hand we observe a positive correlation between the aggregate demand shocks and the US stock market return. On the other hand, this period does not justify any precautionary actions in the oil market. Consumer sentiment has been shifted away from precautionary actions, given the good economic conditions. This explains the almost zero correlation that we observe between the US stock market returns and the oil-market specific shocks. However, the two negative correlations between the US stock market returns and the oilmarket specific shocks that are observed in 2003 and 2005 can be justified by the conflict in Iraq in 2003, the conflict in Nigeria in 2005 and the hurricanes of Katrina and Rita in 2005. 
The divergence of the correlations between the two demand-side shocks and the US stock market returns during the period 2012-2013 can be explained by the Syrian civil war, as well as, the continued conflicts in the Middle East crisis. These events trigger positive oil-market specific shocks (i.e. price hikes) and stock markets respond negatively to such news. This can explain the downward trend of the correlation between the oil-market specific shocks and the US stock market returns from 2011 onwards, as well as, their negative correlation in the post-2012 period. On the other hand, the correlation between aggregate demand shocks and the US stock market returns continues to be positive, as expected.

The fact that aggregate demand shocks and oil-market specific shocks do not diverge during the crisis can be explained by the fact that oil demand during this period was extremely low due to the severe economic conditions across the world. Thus, there is a lower aggregate demand, lower consumption of oil and thus lower uncertainty about its future availability, pushing oil prices downwards. This is also depicted in Figure 2, where a significant drop in both demand-side shocks can be observed during the global financial crisis. In addition, stock markets were declining in this period. Hence, overall we do expect this positive correlation between the stock market returns and each of the two demand side shocks.

Regarding the Shanghai Composite index, correlations are generally lower compared to those of the US market. More specifically, aggregate demand shocks mainly exhibit a low positive relationship with Chinese stock market returns, apart from the period 2007-2009, where a high positive correlation is observed. Oil-market specific demand shocks generate very low correlation levels with Shanghai composite index returns, which fluctuate between both positive and negative levels. There are two periods which exhibit a markedly different behaviour, which are from 1997 until 1999 and from 2008 until mid-2009. Finally, Chinese stock market returns exhibit mainly a very low positive correlation with supply-side oil shocks, with a notable peak in the correlation observed in 1999.

Interestingly, the correlation of changes in oil price returns due to supply-side shocks with US stock returns (negative to zero) and with Chinese stock returns (moderately positive) show very different patterns. It is useful to offer some explanation as to why this might be so. A brief look at the 2014 edition of the BP Statistical Review of World Energy (British Petroleum, 2014) reveals some interesting features of import diversity that may help to explain this. The US and China each have a different set of import partners: For the US the main import partner is Canada, 
with additional major supply streams coming from the Middle East, South and Central America, Mexico and West Africa; China conversely has the Middle East as its dominant supplier of oil, with large quantities from West Africa, The Former Soviet Union, Other Asia Pacific countries and also South and Central America. Since the import portfolios differ, there would naturally be different economic uncertainties created by a supply-side disruption which would almost certainly be a localised event. That is to say for example, a supply disruption in Canada would evidently be a major concern for US oil imports providing more than $30 \%$ of US imported oil, but Canadian oil represents only around $0.4 \%$ of the Chinese oil import portfolio. Put another way, the source of the supply disruptions will play a role in describing the differences in the responses by the US and Chinese stock markets. Finally in attempting to justify why the correlation for China might be positive compared to a negative or zero correlation for the US, we defer to the fact that these economies are each in very different stages of economic development, the positive correlation for China may well be a temporary phenomenon as it passes through the stages of transition from a developing towards a developed economy.

So far we have documented that the behaviour between the two stock market returns and oil price shocks differ significantly. The next step in our analysis is to examine the aforementioned correlations during some key important events that triggered certain oil price shocks, similarly to Filis et al. (2011). Adapted from Filis et al. (2011), Table 2 summarises the oil price shocks over time as these have been identified by Kilian (2009) and Hamilton (2009a,b).

\section{[TABLE 2 HERE]}

It has to this point been illustrated that the US market is generally more responsive to oil price shocks compared to the Chinese stock market. This is even in the case of the Asian economic crisis of 1997 where the correlation between the Shanghai Composite index returns and the aggregate demand shocks fluctuated around 0.05, whereas, at the same time the correlation was at about 0.12 for the NYSE. Another important finding is the difference in correlation levels between stock market returns and aggregate demand shocks during the Chinese economic boom. Over this period the correlation between the NYSE index and aggregate demand shocks was fluctuating between 0.13 and 0.20, whereas for the Shanghai Composite was between 0.10 and 0.37. The strong positive correlation exhibited in the Chinese stock market during 2007 is expected and a plausible explanation is that the booming of the Chinese economy at that period was driving both oil prices and the local stock market index to higher levels. Hamilton (2009b) 
has also documented that the significant rise in oil prices that was observed in this period can be explained by the Chinese industrialisation and growth. Furthermore, the latest global financial crisis (2007-09) caused an important increase in the correlation levels for both China and the US, signifying the importance of this crisis in both oil and stock markets. Still, though, there is a substantial difference between the two stock markets as the correlation for China peaked at the level of 0.39, whereas for the US it was at the level of 0.56 .

Turning our attention to the correlations between oil-market specific demand shocks and stock market returns, Figure 3 highlights that the 9/11 terrorist attack in the US was associated with a moderate positive correlation between the NYSE index and oil-market specific demand shocks (about 0.22). The same correlation for the Shanghai Composite index was almost zero implying that even though the terrorist attack in US affected oil prices and the US stock market, it did not have a major impact in the Chinese stock market. Surprisingly, the correlation between the oilmarket specific demand shocks and stock market returns during the second invasion in Iraq (19 March to 1 May 2003) was almost zero for both markets, despite the fact that the NYSE and the Shanghai Composite indices exhibited a moderate increase during these months. This could be suggestive of the fact that this event did not have an impact on oil prices, whereas both stock markets reacted positively to it.

Figure 3 further reveals that during the supply-side shocks of 1998-99 and 2002 the NYSE index exhibited a somewhat different behaviour, with a correlation level of about -0.10 for the former period and about 0.20 for the latter year. On the contrary, the correlation for the Shanghai Composite index was mainly positive during 1998-1999 (ranging between 0.02 and 0.33). For the year 2002 the correlation fluctuated between 0.08 and 0.17 , suggesting a lower positive correlation compared to the NYSE index.

The evidence broadly shows that all correlations exhibit different patterns during the two US recessions that are covered by our sample. More specifically, during the early 2000 recession all oil price shocks exhibit a moderate correlation of about 0.20 with the NYSE index returns, whereas different oil price shocks showed a different correlation pattern with the Shanghai Composite index returns (i.e. negative correlation with oil-market specific shocks, low positive correlation with supply-side shocks and moderate correlation with aggregate demand shocks). This does not hold true for the 2007/09 global financial crisis where the demand side shocks demonstrated a significant increase in their correlation with the two indices. This is indicative of 
the fact that the latest US recession, which originated from the financial crisis, had a major impact not only in the US but also around the world. It is also indicative of the fact that the latest financial crisis negatively affected both the financial and oil markets. Considering that the 2007/09 global financial crisis had a severe demand side effect on the economies, the low correlations that are observed between the supply-side shocks and the two indices are expected.

Overall, we document that the relationship between the three types of oil price shocks and stock market returns is not constant over time and it varies depending on the events that take place in certain times. We also find that the US market seems to be more responsive to oil price shocks, regardless of their origin. Thus, the risk diversification opportunities between oil price changes and stock market returns are seemingly lower for the NYSE index compared to the Shanghai Composite index. Finally, consistent with Broadstock et al. (2012), the correlation patterns observed for the Shanghai Composite index illustrate that the Chinese stock market did not seem to be particularly influenced from the oil market between 1998 and 2007.

A plausible explanation of this resistance of the Chinese stock market to oil price shocks during the period 1998-2007 can be attributed to the fact that the Chinese economy experienced persistent high growth during this period enabling China to be relatively less influenced by oil price shocks. This is also documented by Nguyen and Bhatti (2012) who maintain that negative effects of oil prices shocks are absorbed by the Chinese economic growth. However, as domestic urbanisation and industrialisation continues, China is becoming increasingly more influenced by international factors, and since the step-change in the structure and nature of the global economy that took place since 2007 we can observe that its stock market is more responsive to global oil price shocks than it had previously been. This latter observation could in part reflect that China has become an increasingly popular prospect for international investors who are more likely to adjust their holdings in stock markets in response to international shocks, such as oil price shocks.

\subsubsection{Industrial sector indices}

The discussion so far has considered the broad similarities and differences of the aggregate stock markets in China and the US. However, as already widely documented in existing literature, oil price pass through effects vary across industry. The next step of our analysis is then to examine these correlations using industrial sector returns. Arouri et al. (2012, p.611) claim that "the use of equity sector indices is, in our opinions, advantageous because market aggregation may mask 
the characteristics of various sectors". In this section we have chosen to focus indicatively on five key industrial sectors that are expected to be responsive to oil price shocks. These sectors are broadly consistent with those considered in Kilian and Park (2009). Specifically we consider: Metals \& Mining, Oil \& Gas, Retail, Technology and the Banking sector.

Figure 4 shows the time-varying correlations for the two oil-related sectors of our sample, i.e. Metals \& Mining and Oil \& Gas.

\section{[FIGURE 4 HERE]}

As discussed in Section 1, existing evidence suggests that these two sectors are positively influenced by oil price changes. The time-varying correlations offer partial, but not complete, support to this evidence. More specifically, across the US sectors, correlation levels are generally positive, although some low negative correlations exist with oil-market specific demand and supply-side shocks during our sample period. In addition, aggregate demand and oil-market specific demand shocks are highly correlated with the Metals \& Mining sector, whereas oilmarket specific demand shocks are more strongly correlated with the Oil \& Gas sector. Surprisingly, though, the Chinese sectors for Metals \& Mining and Oil \& Gas exhibit low positive correlations with all three oil price shocks. These correlations are particularly low during the early period of the study, as well as during the period 2012-2013, where small negative correlations are observed. One notable exception to this trend is during the 2007/09 global financial crisis, when the correlations between the two demand side shocks and the two sectoral indices demonstrate a significant increase.

Next we focus on the Retail and Technology sectors (see Figure 5). Consistent with above, in these two cases we still generally observe that correlations are higher for the US sectors compared to those of China, most apparently for the Technology index. Further, we notice again that the correlations for the Chinese sectors tend to fluctuate mostly around low levels of correlation with the exception being the period of the 2007/09 global financial crisis. Both sectors are influenced positively, as well as, negatively by the three oil price shocks, hence we cannot observe a persistent one way correlation between the Retail and Technology index returns and oil price shocks of any type. Having said that, the only exception is the correlation level between the US Technology index and the aggregate demand shocks, where a constantly positive correlation is exhibited. This is can be explained by the fact that even though positive aggregate demand shocks increase the price of oil, they also signify an increase in aggregate demand, 
which is regarded as positive news and thus certain stock prices could exhibit more bullish behaviour. These findings are in contrast with much of the readily available information from the existing literature which generally suggests that oil price changes are negatively influencing both sectors (see Section 1). This difference in the results could exist due to the fact that previous studies did not decompose oil price shocks into their different sources and also that they have examined the said relationships at a static environment. Our results, though, are however much more consistent with theoretical priors, and in this regard they are much more plausible.

\section{[FIGURE 5 HERE]}

The last sector to be considered is the Banking sector. Figure 6 reveals that the Chinese Banking sector is more responsive to oil price shocks compared to the US banking sector.

\section{[FIGURE 6 HERE]}

More specifically, the Chinese banking sector is positively correlated (low to moderate) with aggregate demand shocks and negatively correlated with oil-market specific demand shocks. Supply-side shocks and the Chinese banking sector's returns exhibit a low to zero correlation level, with the exception of the period 1999-2001. By contrast, correlations between the US banking sector's returns and the two demand side shocks are mainly positive but low. In addition, the US banking sector has a low correlation with supply-side shocks, which fluctuates between both positive and negative correlations. Overall, the findings imply that demand-side oil price shocks are less severe upon the US banking sector than they are for China, whereas the supplyside shocks do not really seem to affect either index.

In attempting to draw some policy implications that can be used to inform investment decisions several points can be offered. The first is that financial investment decisions can be supported by a better understanding of when and what types of oil shocks impact upon stock market returns. Furthermore, by considering the returns of specific industrial sub-sectors investors are provided a much clearer understanding of which types of stocks may be safer than others to oil shocks. In addition, due to the positive correlation between oil shocks and overall stock indices, turbulence the oil market could not be considered a 'safe haven' to shield against potential losses in wider stock market portfolios. Finally, the evidence of systematic dynamic correlations presented in this paper should provide a means of establishing reasonable short-term expectations/projections of oil shock impacts upon stock markets, potentially offering insights into hedging strategies. 
This last point has not been discussed here, since to do so formally would have altered the focus of the paper substantially, though is potentially worth exploring in further work.

\section{Conclusions}

The aim of this study is to examine the time-varying correlations between oil prices shocks of different types (supply-side, aggregate demand and oil-market specific demand) and stock market returns, using a Scalar-BEKK model. For this study we consider the aggregate stock market indices from two countries, China and the US. In addition, we also consider correlations from key selected industrial sectors, namely Metals \& Mining, Oil \& Gas, Retail, Technology and Banking. The sample period runs from 1995 until 2012.

Importantly, the findings of this study complement the existing literature in two regards. First, some existing literature has already established that stock markets tend to respond differently to different oil price shocks (see, inter alia, Degiannakis et al., 2014; Basher et al., 2012; Kilian and Lewis, 2011; Filis et al., 2011; Kilian and Park, 2009; Kilian, 2009; Apergis and Miller, 2009). Nevertheless, the existing literature has not focused on the time-varying relationship between the individual oil price shocks and stock market returns. In this respect, we find that the stock market response to oil price shocks is different over time. More specifically, the evidence suggest that the US stock market is more responsive to oil price shocks compared to the Chinese stock market, as it exhibits a higher level of correlation with oil price shocks throughout the studied period. In addition, the US market is always positively related with the aggregate demand shocks, whereas this does not hold true for China. The results apply to both aggregate stock market and industrial sectors returns, although the reverse observations can be made for the banking sectors of these two countries. The second key contribution to existing literature is that we document different responses across industries, suggesting that investors need to be aware of the different behaviour of the industrial sectors towards oil price shocks. In some cases this leads to important and internally consistent conclusions (with respect to macro-economic theoretical priors). Thus, the insights offered here are more informative.

The analysis given here is in our opinion interesting, building on the innovative and insightful contributions of Kilian (2009) and Kilian and Park (2009). There yet remain many further ways to explore and extend the analytical framework. Perhaps the most obvious "limitation" for want of a better term is that the analysis is only semi-structural. More specifically, although the oil 
market and economic activity measure might reflect some form of global market structure, the financial indicators are region specific. This is not a weakness per se especially given the VAR is structural, hence the impacts of oil on the global economy are not influenced by the financial markets. Nonetheless it would be interesting to "complete" the structural model by integrating some combined measure of global financial markets. Other issues deserving of more attention are the possible asymmetries in the effect of oil price changes which could be handled more explicitly and also potential structural instabilities over the sample period, both of which have been the focus of numerous prominent studies.

There may be one relevant institutional feature relevant in interpreting the conclusions that has not yet been mentioned. The regulation of financial markets in US and China has one very distinctive difference in terms of the freedom of price movements. Specifically, Chinese stock markets are regulated to allow prices to vary only within a $10 \%$ window on any given day. In the present data it is unclear whether this limit is met frequently or not, but nonetheless could be an influencing factor in mediating a relatively smaller correlation than compared to the US where no such controls are in place. This however would be best considered in future studies using firm level data, rather than the portfolios considered here.

\section{Acknowledgements}

We thank the editor Prof. Geoffrey Booth, the anonymous referee and Prof. Lutz Kilian for their constructive comments and suggestions which helped us to improve the scope and clarity of the paper. We also thank the participants of the $45^{\text {th }}$ Annual Money Macro and Finance Conference, the Joint East Asian Studies Conference and the 2013 Chinese Economists Society Annual Conference for the valuable comments. This work begun during David's time as visiting scholar with Portsmouth University during 2012. The views expressed are those of the authors and should not be interpreted as those of their respective institutions. The authors are solely responsible for any remaining errors and deficiencies.

\section{References}

Abhyankar, A., Xu, B., Wang, J. 2013. Oil price shocks and the stock market: Evidence from Japan. Energy Journal 34, 199-222.

Alquist, R., Kilian, L. 2010. What do we learn from the price of crude oil futures? Journal of Applied Econometrics 25, 539-573. 
Amano, R.A., Van Norden, S., 1998. Oil prices and the rise and fall of the US real exchange rate. Journal of International Money and Finance 17, 299-316.

Antonakakis, N., Filis, G. 2013. Oil prices and stock market correlation: A time-varying approach. International Journal of Energy and Statistics 1, 17-29.

Apergis, N., Miller, S.M. 2009. Do structural oil-market shocks affect stock prices? Energy Economics 31, 569-575.

Arouri, M.E.H. 2011. Does crude oil move stock markets in Europe? A sector investigation. Economic Modelling 28, 1716-1725.

Arouri, M.E.H. 2012. Stock returns and oil price changes in Europe: A sector analysis. The Manchester School 80, 237-261.

Arouri, M.E.H., Jouini, J., Nguyen, D.K. 2011. Volatility spillovers between oil prices and stock sector returns: Implications for portfolio management. Journal of International Money and Finance 30, 1387-1405.

Arouri, M.E.H., Jouini, J., Nguyen, D.K. 2012. On the impacts of oil price fluctuations on European equity markets: Volatility spillover and hedging effectiveness. Energy Economics 34, 611-617.

Arouri, M.E.H., Nguyen, D.K. 2010. Oil prices, stock markets and portfolio investment: Evidence from sector analysis in Europe over the last decade. Energy Policy 38, 45284539.

Asteriou, D., Bashmakova, Y. 2013. Assessing the impact of oil returns on emerging stock markets: A panel data approach for ten Central and Eastern European Countries. Energy Economics 38, 204-211.

Baba, Y., Engle, R.F., Kraft, D.F., Kroner, K.F. 1991. Multivariate simultaneous generalized ARCH, Unpublished manuscript, Department of Economics, University of California, San Diego.

Bachmeier, L. 2008. Monetary policy and the transmission of oil shocks. Journal of Macroeconomics 30, 1738-1755.

Barsky, R.B., Kilian, L. 2004. Oil and the macroeconomy since the 1970s. Journal of Economic Perspectives 18, 115-134.

Basher, S.A., Haug, A.A., Sadorsky, P. 2012. Oil prices, exchange rates and emerging stock markets. Energy Economics 34, 227-240. 
Baumeister, C., Peersman, G. 2012. Time-varying effects of oil supply shocks on the US economy. Bank of Canada Working Paper Series, WP2012-02.

Bernanke, S.B., Gertler, M., Watson, M. 1997. Systematic monetary policy and the effects of oil price shocks. Brookings Papers on Economic Activity 1, 91-148.

Blanchard, J.O., Gali, J. 2007. The macroeconomic effects of oil price shocks. Why are the 2000s so different than the 1970s? National Bureau of Economic Research, Working Paper 13368.

Boyer, M.M., Filion, D. 2007. Common and fundamental factors in stock returns of Canadian oil and gas companies. Energy Economics 29, 428-453.

British Petroleum. 2014. BP Statistical Review of World Energy 2014. http://www.bp.com/content/dam/bp/pdf/Energy-economics/statistical-review2014/BP-statistical-review-of-world-energy-2014-full-report.pdf

Broadstock, D.C., Cao, H., Zhang, D. 2012. Oil shocks and their impact on energy related stocks in China. Energy Economics 34, 1888-1895.

Brown, P.A.S., Yücel, M.K. 2002. Energy prices and aggregate economic activity: an interpretative survey. The Quarterly Review of Economics and Finance 42, 193-208.

Burbidge, J., Harrison, A. 1984. Testing for the effects of oil-price rises using vector autoregressions. International Economic Review 25, 459-484.

Buyuksahin, B., Haigh, M.S., Robe, M.A. 2010. Commodities and equities: Ever a 'market of one'?, Journal of Alternative Investments 12, 76-95.

Buyuksahin, B., Robe, M.A. 2011. Does 'paper oil' matter? Energy markets' financialization and equity-commodity co-movements. Working paper. The American University.

Caporin, M., McAleer, M. 2008. Scalar BEKK and indirect DCC. Journal of Forecasting 27, 537-549.

Caporin, M., McAleer, M. 2011. Do we really need both BEKK and DCC? A tale of two covariance models. Journal of Economic Surveys, DOI: 10.1111/j.14676419.2011.00683.x

Chang, C.L., McAleer, M., Tansuchat R. 2010. Conditional correlations and volatility spillovers between crude oil and stock index returns. Discussion Paper, Kyoto Institute of Economic Research, KIER Discussion Paper Series 715. 
Chen, S.S. 2009. Do higher oil prices push the stock market into bear territory? Energy Economics 32, 490-495.

Chen, W., Hamori, S., Kinkyo, T. 2014. Macroeconomic impacts of oil prices and underlying financial shocks. Journal of International Financial Markets, Institutions and Money 29, 1-12.

Choi K., Hammoudeh, S. 2010. Volatility behavior of oil, industrial commodity and stock markets in a regime-switching environment. Energy Policy 38, 4388-4399.

Ciner, C. 2001. Energy shocks and financial markets: nonlinear linkages. Studies in Nonlinear Dynamics \& Econometrics 5, 203-212.

Ciner, C. 2013. Oil and stock returns: Frequency domain evidence. Journal of International Financial Markets, Institutions and Money 23, 1-11.

Darrat, A.F., Gilley, O.W., Meyer, D.J. 1996. US oil consumption, oil prices, and the macroeconomy. Empirical Economics 21, 317-334.

Degiannakis, S., Filis, G., Floros, C. 2013. Oil and stock returns: Evidence from European industrial sector indices in a time-varying environment. Journal of International Financial Markets, Institutions and Money 26, 175-191.

Degiannakis, S., Filis, G., Kizys, R. 2014. The effects of oil price shocks on stock market volatility: Evidence from European data. The Energy Journal 35, 35-56.

Ding, Z., Engle, R. 2001. Large scale conditional covariance modelling, estimation and testing. Academia Economic Papers 29, 157-184.

Driesprong, G., Jacobsen, B., Maat, B. 2008. Striking oil: another puzzle? Journal of Financial Economics 89, 307-327.

El-Sharif, I., Brown, D., Burton, B., Nixon, B., Russell, A. 2005. Evidence on the nature and extent of the relationship between oil prices and equity values in the UK. Energy Economics 27, 819-830.

Elyasiani, E., Mansur, I., Odusami, B. 2011. Oil price shocks and industry stock returns. Energy Economics 33, 966-974.

Engle, F.R. 2002. Dynamic conditional correlation: a simple class of multivariate GARCH models. Journal of Business and Economic Statistics 20, 339-350.

Engle, R.F., Kroner, K.F. 1995. Multivariate simultaneous generalized ARCH. Economic Theory, 11, 122-150. 
Fattouh B, Kilian L, Mahadeva L. 2013. The role of speculation in oil markets: what have we learned so far? Energy Journal 34, 7-33.

Filis, G. 2010. Macro economy, stock market and oil prices: Do meaningful relationships exist among their cyclical fluctuations? Energy Economics 32, 877-886.

Filis, G., Chatziantoniou, I. 2013. Financial and monetary policy responses to oil price shocks: evidence from oil-importing and oil-exporting countries. Review of Quantitative Finance and Accounting, 1-21.

Filis, G., Degiannakis, S., Floros, C. 2011. Dynamic correlation between stock market and oil prices: The case of oil-importing and oil-exporting countries. International Review of Financial Analysis 20, 152-164.

Gjerde, Ø., Sættem, F. 1999. Causal relations among stock returns and macroeconomic variables in a small, open economy. Journal of International Financial Markets, Institutions and Money 9, 61-74.

Gogineni, S. 2010. Oil and the stock market: an industry level analysis. Financial Review 45, 995-1010.

Hamilton, J.D. 1983. Oil and the macroeconomy since World War II. Journal of Political Economy 91, 228-248.

Hamilton, J.D. 1996. This is what happened to the oil price-macroeconomy relationship. Journal of Monetary Economics 38, 215-220.

Hamilton, J.D. 2008. Oil and the macroeconomy. New Palgrave Dictionary of Economics, 2nd edition, edited by Durlauf, S. and Blume, L., Palgrave McMillan Ltd.

Hamilton, J.D. 2009a. Understanding crude oil prices. Energy Journal 30, 179-206.

Hamilton, J.D. 2009b. Causes and consequences of the oil shock of 2007-08. Brookings Papers on Economic Activity Spring, 215-261.

Hamilton, J.D., Herrera, A.M. 2004. Oil shocks and aggregate macroeconomic behavior: The role of monetary policy. Journal of Money, Credit, and Banking 36, 265-286.

Hamilton, J.D., Wu, J.C. 2012. Risk Premia in Crude Oil Futures Prices. Working paper. University of California at San Diego.

Hammoudeh, S., Li, H. 2005. Oil sensitivity and systematic risk in oil-sensitive stock indices. Journal of Economics and Business 57, 1-21. 
Henriques, I., Sadorsky, P. 2008. Oil prices and the stock prices of alternative energy companies. Energy Economics 30, 998-1010.

Hooker, A.M. 1996. What happened to the oil price-macroeconomy relationship? Journal of Monetary Economics 38, 195-213.

Hooker, A.M. 2002. Are oil shocks inflationary? Asymmetric and nonlinear specifications versus changes in regime. Journal of Money, Credit and Banking 34, 540-561.

Huang, R.D, Masulis, R.W., Stoll, H.R. 1996. Energy shocks and financial markets. Journal of Futures Markets 16, 1-27.

Hutchison, M.M., 1993. Structural change and the macroeconomic effects of oil shocks: empirical evidence from the United States and Japan. Journal of International Money and Finance 12, 587-606.

Jbir, R., Zouari-Ghorbel, S. 2009. Recent oil price shock and Tunisian economy. Energy Policy 37, 1041-1051.

Jones, C.M., Kaul, G. 1996. Oil and the stock markets. The Journal of Finance 51, 463-491.

Jones, D.W., Lelby, P.N., Paik, I.K. 2004. Oil prices shocks and the macroeconomy: What has been learned since. Energy Journal 25, 1-32.

Kang, W., Ratti, R. A. 2013. Oil shocks, policy uncertainty and stock market return. Journal of International Financial Markets, Institutions and Money 26, 305-318.

Kilian, L. 2008a. Exogenous oil supply shocks: how big are they and how much do they matter for the US economy? Review of Economics and Statistics 90, 216-240.

Kilian, L. 2008b. The economic effects of energy price shocks. Journal of Economic Literature 46, 871-909.

Kilian, L. 2009. Not all oil shocks are alike: Disentangling demand and supply shocks in the crude oil market. American Economic Review 99, 1053-1069.

Kilian, L., Lee, T. K. 2014. Quantifying the speculative component in the real price of oil: The role of global oil inventories. Journal of International Money and Finance 42, 71-87.

Kilian, L., Lewis, L.T. 2011. Does the Fed respond to oil price shocks? Economic Journal 121, 1047-1072.

Kilian, L., Murphy, D.P. 2014. The role of inventories and speculative trading in the global market for crude oil. Journal of Applied Econometrics 29, 454-478. 
Kilian, L., Park, C. 2009. The impact of oil price shocks on the US stock market, International Economic Review 50, 1267-1287.

Laopodis, N. T. 2011. Equity prices and macroeconomic fundamentals: International evidence. Journal of International Financial Markets, Institutions and Money 21, 247-276.

Leduc, S., Sill, K. 2004. A quantitative analysis of oil-price shocks, systematic monetary policy and economic downturns. Journal of Monetary Economics 51, 781-808.

Lee, Y-H., Chiou, J-S. 2011. Oil sensitivity and its asymmetric impact on the stock market. Energy 36, 168-174.

Lescaroux, F., Mignon, V. 2009. The symposium on 'China's impact on the global economy': Measuring the effects of oil prices on China's economy: A factor-augmented vector autoregressive approach. Pacific Economic Review 14, 410-425.

Lippi, F., Nobili, A. 2012. Oil and the macroeconomy: A quantitative structural analysis. Journal of the European Economic Association 10, 1059-1083.

Maghyereh, A. 2004. Oil price shocks and emerging stock markets: A generalized VAR approach. International Journal of Applied Econometrics and Quantitative Studies 1, 27-40.

Miller, J.I., Ratti, R.A. 2009. Crude oil and stock markets: Stability, instability, and bubbles. Energy Economics 31, 559-568.

Mjelde, J. W., Bessler, D.A., 2009. Market integration among electricity markets and their major fuel source markets. Energy Economics 31, 482-491.

Mohanty, S.K., Nandha, M., Turkistani, A.Q., Alaitani, M.Y. 2011. Oil price movements and stock market returns: Evidence from Gulf Cooperation Council (GCC) countries. Global Finance Journal 22, 42-55.

Mork, K.A. 1989. Oil and the macroeconomy when prices go up and down: An extension of Hamilton's results. Journal of Political Economy 91, 740-744.

Mork, K.A., Olsen, O., Mysen, H.T. 1994. Macroeconomic responses to oil price increases and decreases in seven OECD countries. Energy Journal 15, 19-35.

Nakov, A., Pescatori, A. 2010. Oil and the great moderation. The Economic Journal 120, 131156.

Nandha, M., Faff, R. 2008. Does oil move equity prices? A global view. Energy Economics 30, 986-997. 
Narayan, P.K., Sharma, S.S. 2011. New evidence on oil price and firm returns. Journal of Banking and Finance 35, 3253-3262.

Nguyen, C. C., Bhatti, M. I. 2012. Copula model dependency between oil prices and stock markets: Evidence from China and Vietnam. Journal of International Financial Markets, Institutions and Money 22, 758-773.

O'Neill, J.T., Penm, J., Terrell, D.R. 2008. The role of higher oil prices: A case of major developed countries. Research in Finance 24, 287-299.

Papapetrou, E. 2001. Oil price shocks, stock market, economic activity and employment in Greece. Energy Economics 23, 511-532.

Park, J.W., Ratti, R.A. 2008. Oil price shocks and stock markets in the US and 13 European countries. Energy Economics 30, 2587-2608.

Rahman, S., Serletis, A. 2011. The asymmetric effects of oil price shocks. Macroeconomic Dynamics 15, 437-471.

Rotemberg, J.J., Woodford, M. 1996. Imperfect competition and the effects of energy price increases on economic activity. National Bureau of Economic Research, No. w5634.

Sadorsky, P., 2001. Risk factors in stock returns of Canadian oil and gas companies. Energy Economics 23, 17-28.

Scholtens, B., Yurtsever, C. 2012. Oil price shocks and European industries. Energy Economics 34, 1187-1195.

Silvennoinen, A., Terasvirta, T. 2009. Multivariate GARCH Models, Handbook of Financial Time Series, edited by Anderson, T.G. David, R.A. Kreisand Blume, L., Palgrave McMillan Ltd.

Silvennoinen, A., Thorp, S. 2010. Financialization, crisis, and commodity correlation dynamics. Working paper. University of Technology, Sydney.

Swanson, N.R., Granger, C.W.J., 1997. Impulse response functions based on a causal approach to residual orthogonalization in Vector Autoregression. Journal of the American Statistical Association 92, 357-67.

Segal, P. 2011. Oil price shocks and the macroeconomy. Oxford Review of Economic Policy 27, 169-185.

Tang, W., Wu, L., Zhang, Z.X. 2010. Oil price shocks and their short and long-term effects on the Chinese economy. Energy Economics 32, S3-S14. 
Tang, K., Xiong, W. 2012. Index investment and financialization of commodities. Financial Analyst Journal 68, 54-74. 


\section{TABLES}

Table 1: Descriptive statistics of the series under examination, 1995:01-2013:07.

\begin{tabular}{|c|c|c|c|c|c|c|}
\hline & S\&P500 & US_BANKS & US_METALS & US_OIL & US_RETAIL & US_TECH \\
\hline Mean & 0.0037 & 0.0015 & -0.0002 & 0.0065 & 0.0060 & 0.0051 \\
\hline Maximum & 0.1310 & 0.3385 & 0.2671 & 0.1307 & 0.1226 & 0.1933 \\
\hline Minimum & -0.2791 & -0.3372 & -0.7396 & -0.3614 & -0.3233 & -0.3213 \\
\hline Std. Dev. & 0.0469 & 0.0794 & 0.0987 & 0.0592 & 0.0571 & 0.0786 \\
\hline Skewness & -1.2576 & -0.0806 & -1.9136 & -1.2321 & -1.1014 & -0.5719 \\
\hline Kurtosis & 8.2050 & 6.7873 & 16.0630 & 8.4471 & 7.3678 & 4.4573 \\
\hline \multirow[t]{2}{*}{ Jarque-Bera } & $309.1118 *$ & $132.9211^{*}$ & 1713.9170* & $330.6299 *$ & $221.3516^{*}$ & $31.7446 *$ \\
\hline & SHANGHAI & CH_BANKS & CH_METALS & CH_OIL & CH_RETAIL & CH_TECH \\
\hline Mean & 0.0045 & 0.0075 & 0.0139 & 0.0088 & 0.0029 & 0.0131 \\
\hline Maximum & 0.2795 & 0.7600 & 0.4566 & 0.6742 & 0.2555 & 0.3758 \\
\hline Minimum & -0.2867 & -0.4511 & -0.4123 & -0.3616 & -0.2899 & -0.3017 \\
\hline Std. Dev. & 0.0841 & 0.1378 & 0.1165 & 0.1310 & 0.0898 & 0.1066 \\
\hline Skewness & -0.0841 & 1.2809 & 0.0309 & 0.7307 & 0.0601 & 0.1809 \\
\hline Kurtosis & 4.0727 & 9.0670 & 4.4035 & 6.3527 & 3.1421 & 3.5656 \\
\hline \multirow[t]{2}{*}{ Jarque-Bera } & $10.9061 *$ & $401.1832 *$ & $18.25608^{*}$ & $123.7275^{*}$ & 0.3203 & 4.1696 \\
\hline & $\triangle$ OILPROD & GEA & $\triangle \mathrm{OILP}$ & & & \\
\hline Mean & 0.0010 & 0.0245 & 0.0066 & & & \\
\hline Maximum & 0.0267 & 0.5914 & 0.1967 & & & \\
\hline Minimum & -0.0196 & -0.5026 & -0.2976 & & & \\
\hline Std. Dev. & 0.0071 & 0.2721 & 0.0871 & & & \\
\hline Skewness & 0.2073 & 0.2017 & -0.7319 & & & \\
\hline Kurtosis & 4.0531 & 2.0800 & 3.9663 & & & \\
\hline Jarque-Bera & $11.9027 *$ & $9.3759 *$ & $28.5856^{*}$ & & & \\
\hline $\begin{array}{l}\text { Note: The de } \\
\text { names of the } \\
\text { transformed il } \\
* \text { and } * * \text { indic }\end{array}$ & $\begin{array}{l}\text { tive statistic } \\
\text { ustrial secto } \\
\text {-returns as tl } \\
\text { ignificance }\end{array}$ & $\begin{array}{l}\text { respond to th } \\
\text { note the cor } \\
\text { lex reflects it } \\
\text { and } 5 \% \text { leve }\end{array}$ & $\begin{array}{l}\text { g-returns of th } \\
\text { of origin. } \mathrm{G} \\
\text { changes in the } \\
\text { espectively. }\end{array}$ & $\begin{array}{l}\text { eries under } \\
\text { al Econom } \\
\text { bal econon }\end{array}$ & $\begin{array}{l}\text { estigation. US } \\
\text { Activity index } \\
\text { activity. }\end{array}$ & $\begin{array}{l}\text { nd CH in the } \\
\text { GEA) is not }\end{array}$ \\
\hline
\end{tabular}


Table 2: Important oil price shocks over the period 1995-2013.

Event

Asian Economic Crisis

Several oil production cuts by OPEC

Housing market boom

9/11 terrorist attack in US

PdVSA worker's strike

Second war in Iraq

Chinese economic growth

Global financial crisis

Note: These oil price shocks have been identified by Kilian's (2009) and Hamilton's (2009) findings. This table has been adapted from Filis et al. (2011).

\begin{aligned} \multicolumn{1}{c}{ Year } & Oil price shock origin \\ 1997 & Aggregate demand side \\ $1998-1999 &$ Supply side \\ 2000 & Aggregate demand \\ 2001 & Oil-market specific demand \\ 2002 & Supply side \\ 2003 & Oil-market specific demand \\ $2006-2007 &$ Aggregate demand \\ $2007-2008 &$ Aggregate demand \end{aligned}

2001 Oil-market specific demand

2006-2007 Aggregate demand

2007-2008 Aggregate demand 
FIGURES

Figure 1: Time-series plots of data used in the analysis, 1995:1-2013:07.
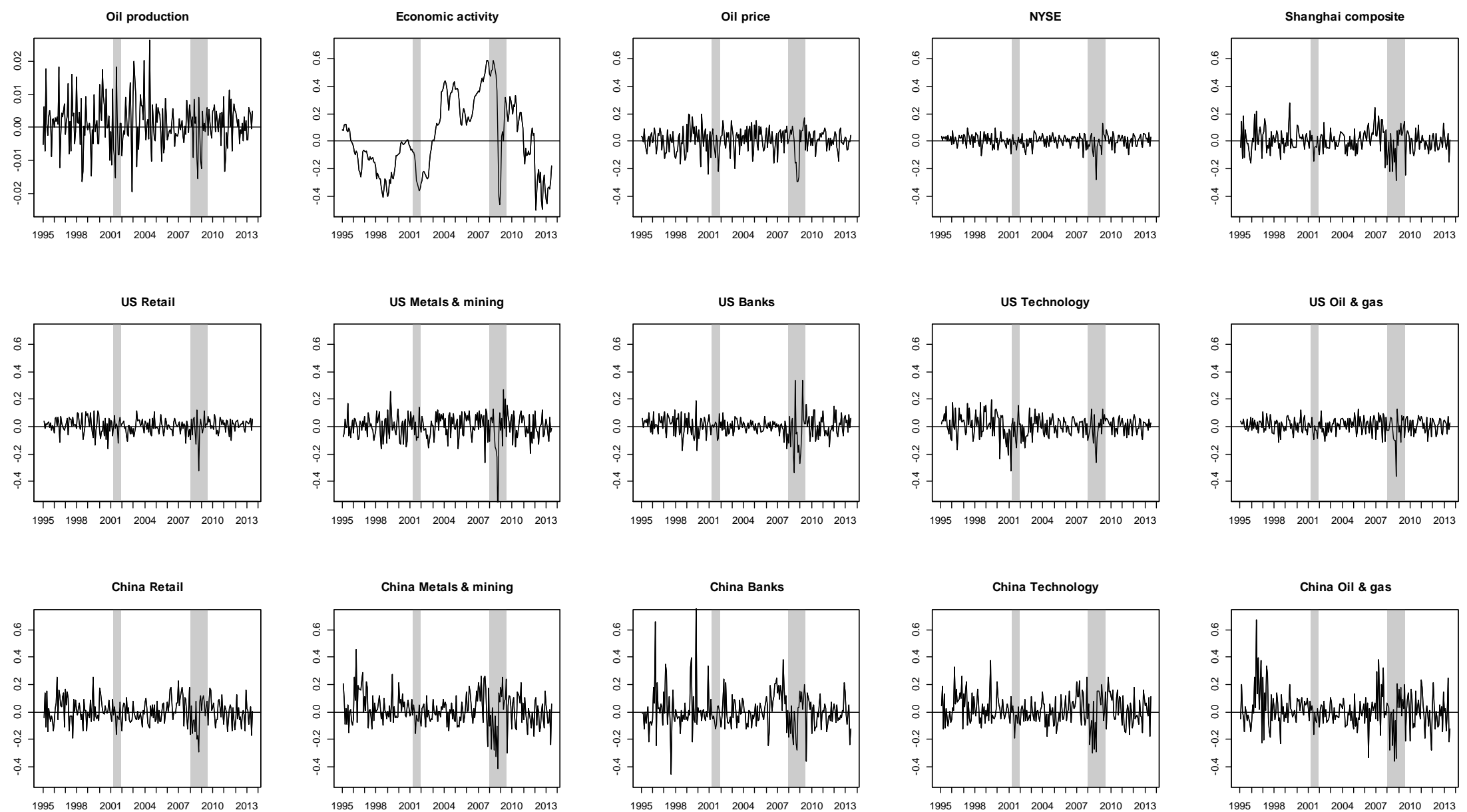
Figure 2: Estimated oil shocks according to their origin, 1995:1-2013:07.

Oil supply shocks

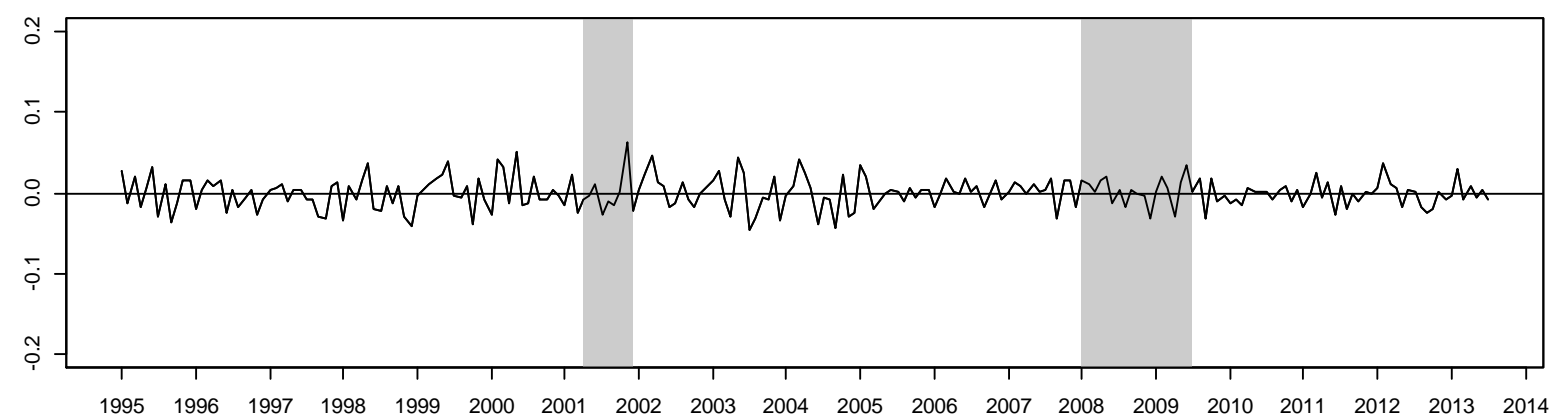

Aggregate demand shocks

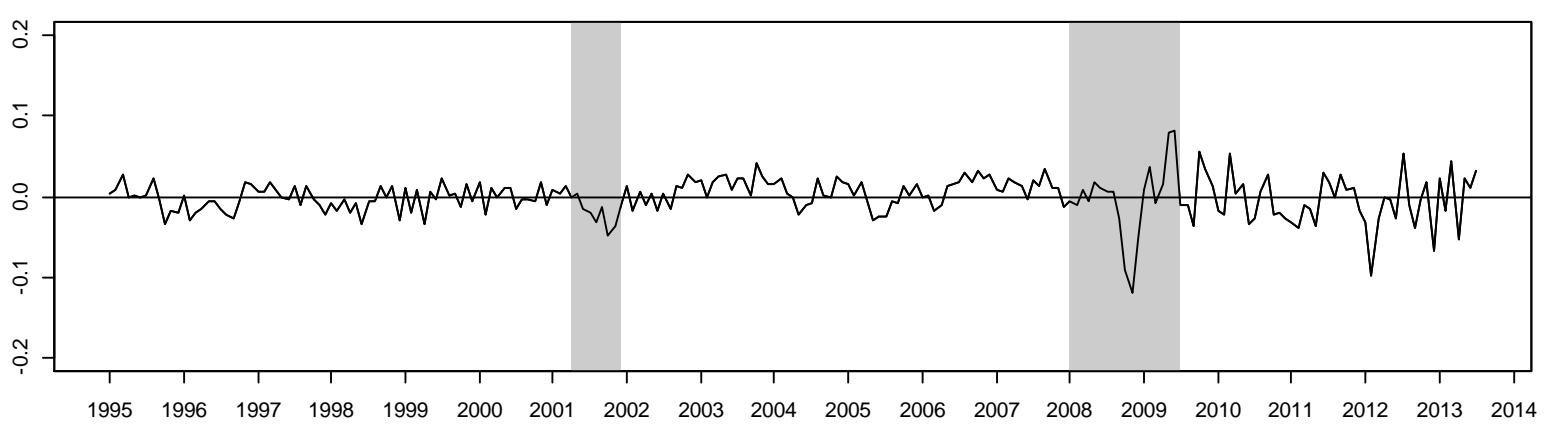

Oil-market specific demand shocks

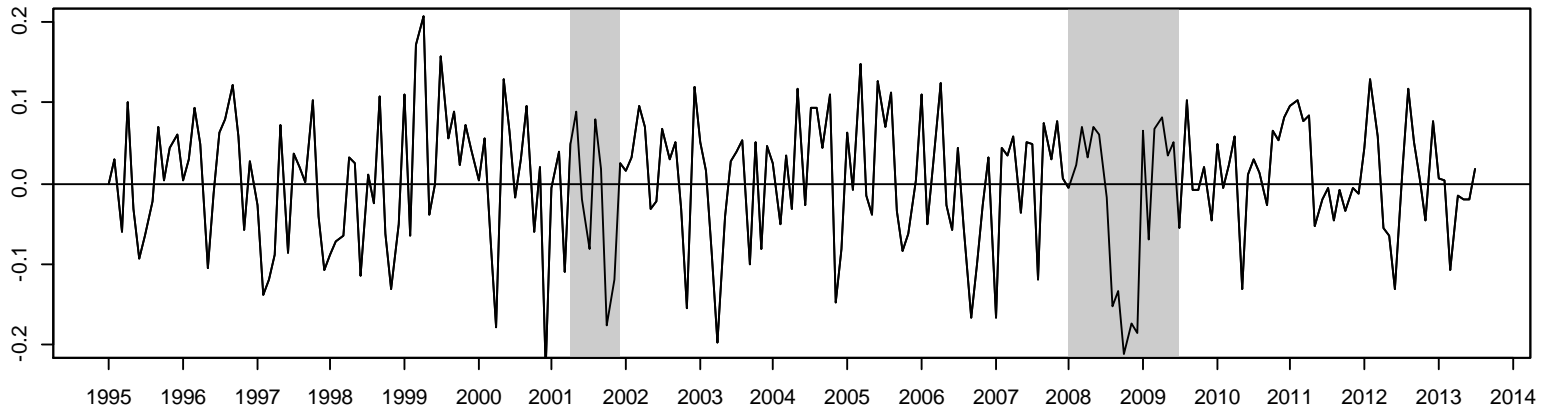


Figure 3: Time-varying correlations of aggregate index returns with oil shocks, 1995:1-2013:07.

NYSE

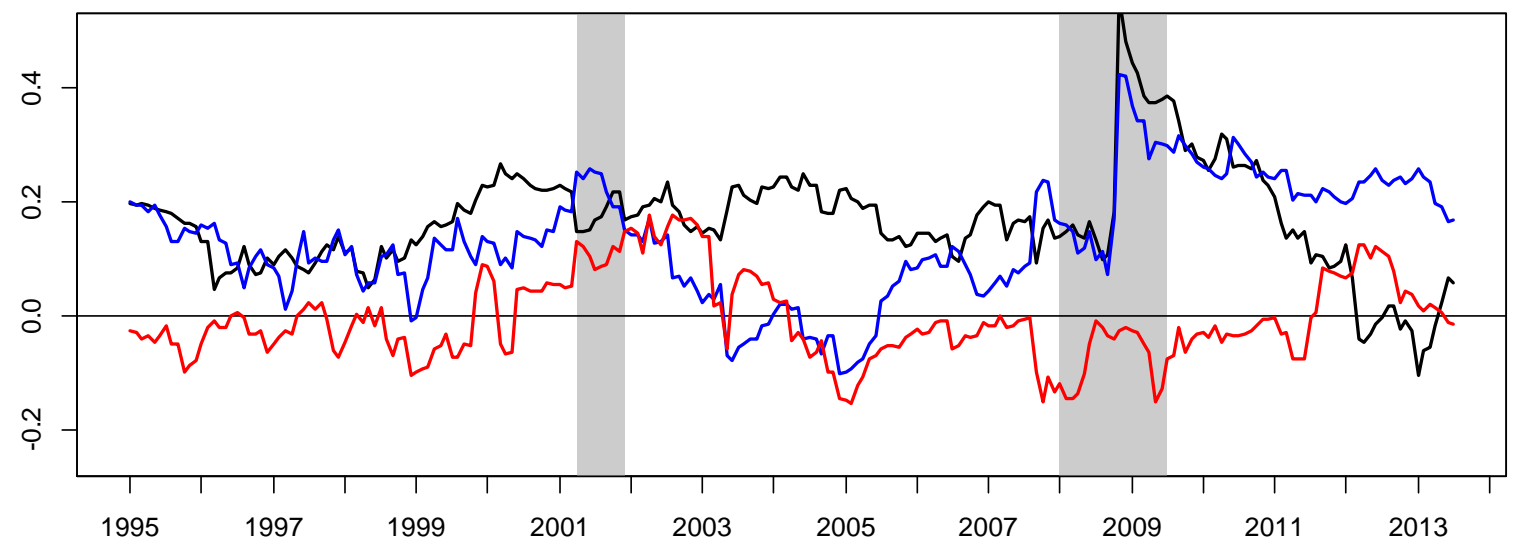

(Black=aggregate demand; Blue=Oil-market specific demand; Red=Oil supply)

\section{China Shanghai Composite}

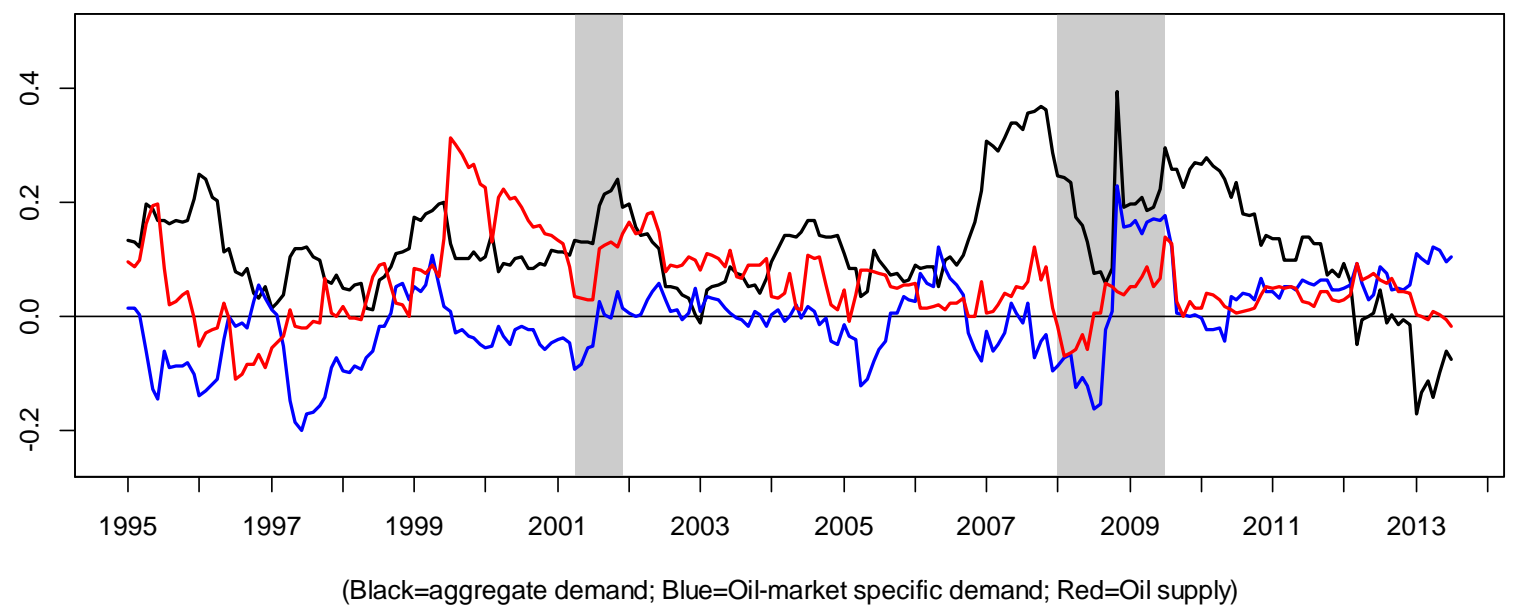


Figure 4: Time-varying correlations of Metals \& Mining and Oil \& Gas sectors returns with oil shocks, 1995:1-2013:07.

US Metals \& mining

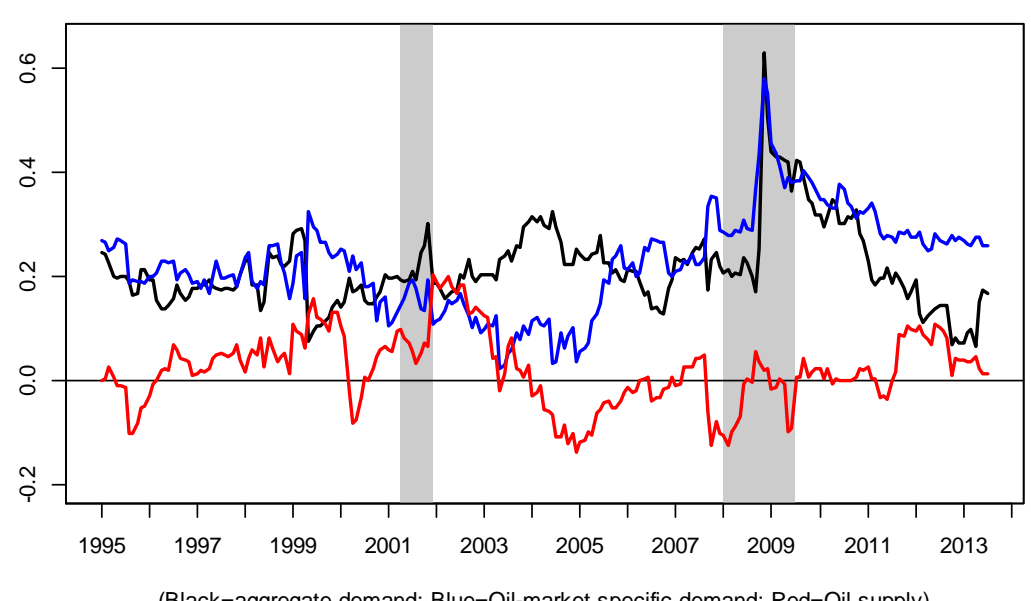

(Black=aggregate demand; Blue=Oil-market specific demand; Red=Oil supply)

China Metals \& mining

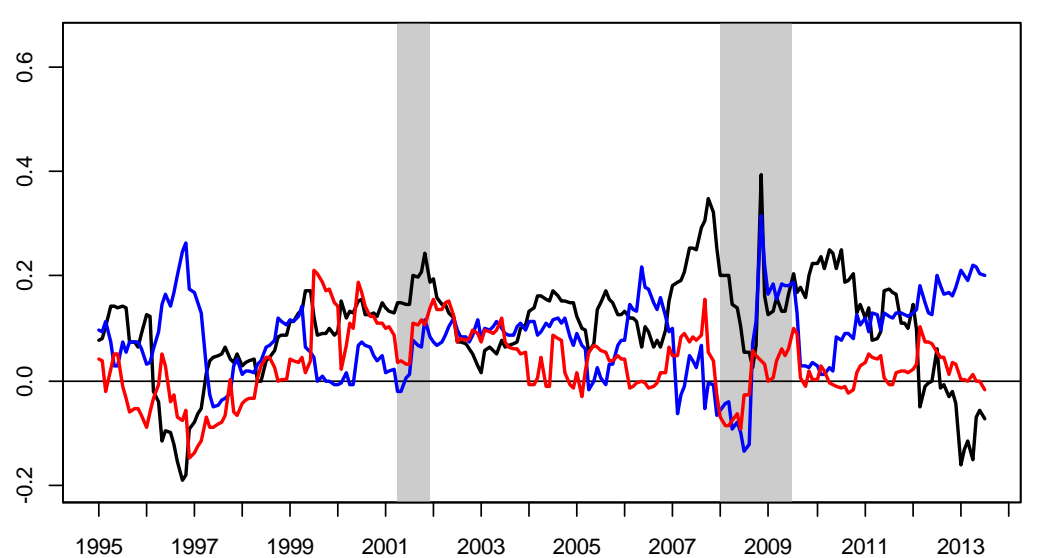

(Black=aggregate demand; Blue=Oil-market specific demand; Red=Oil supply)

\section{US Oil \& gas}

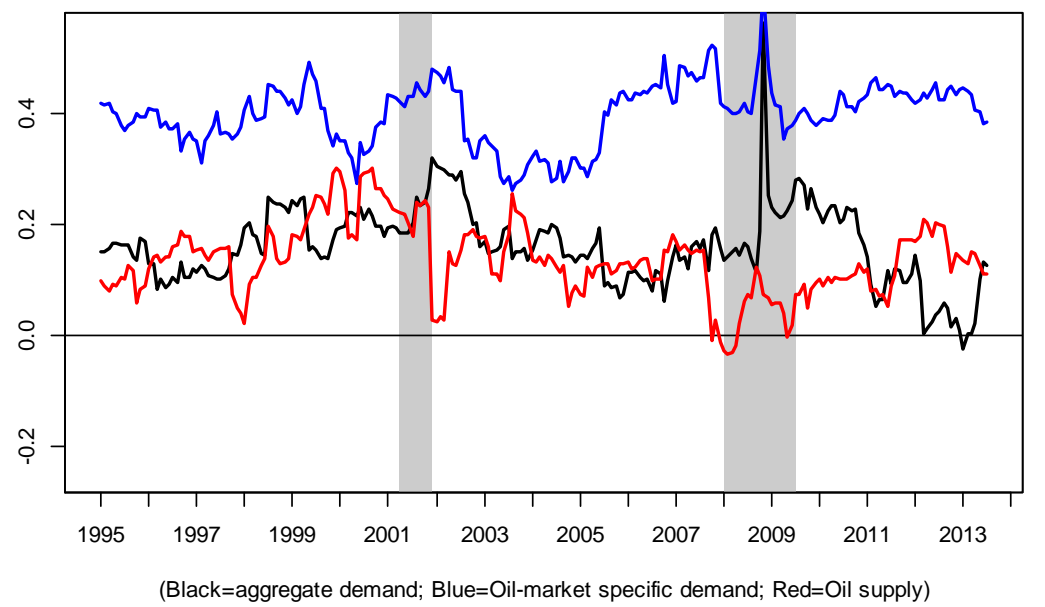

China Oil \& gas

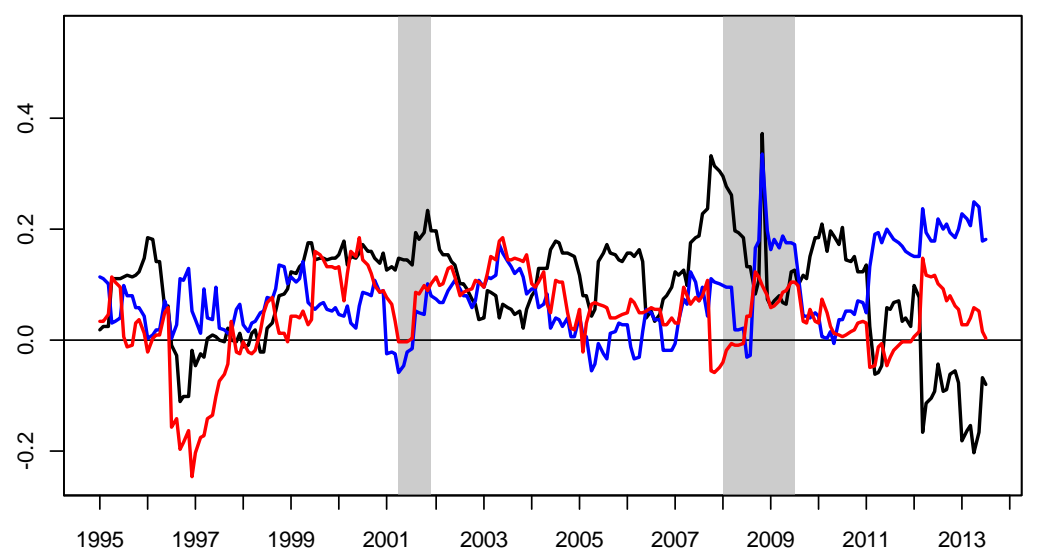

(Black=aggregate demand; Blue=Oil-market specific demand; Red=Oil supply) 
Figure 5: Time-varying correlations of Retail and Technology sectors returns with oil shocks, 1995:1-2013:07.

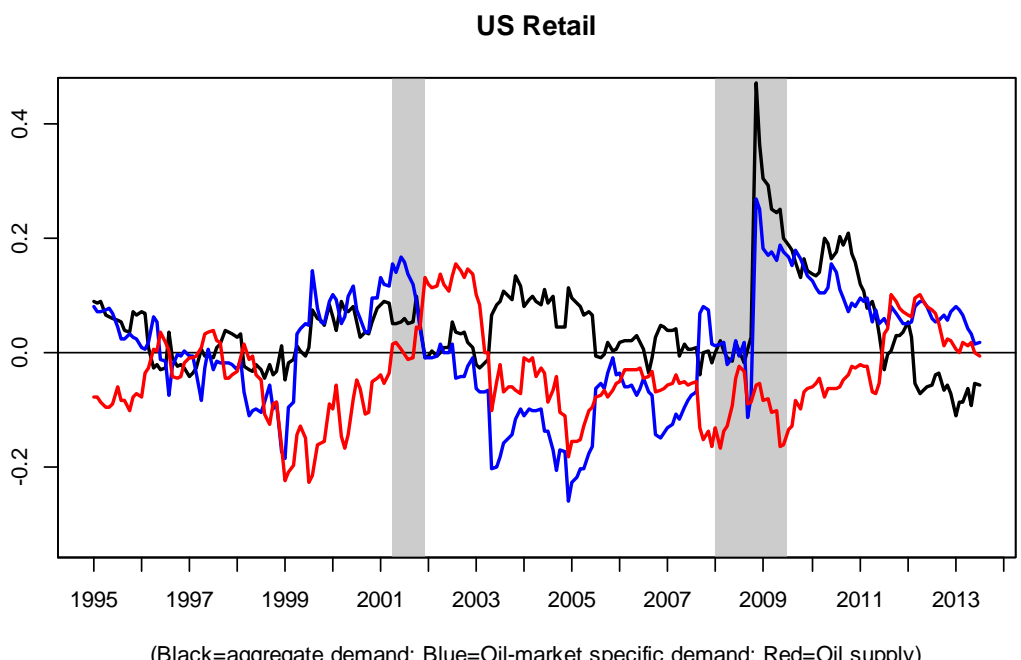

(Black=aggregate demand; Blue=Oil-market specific demand; Red=Oil supply)

\section{China Retail}

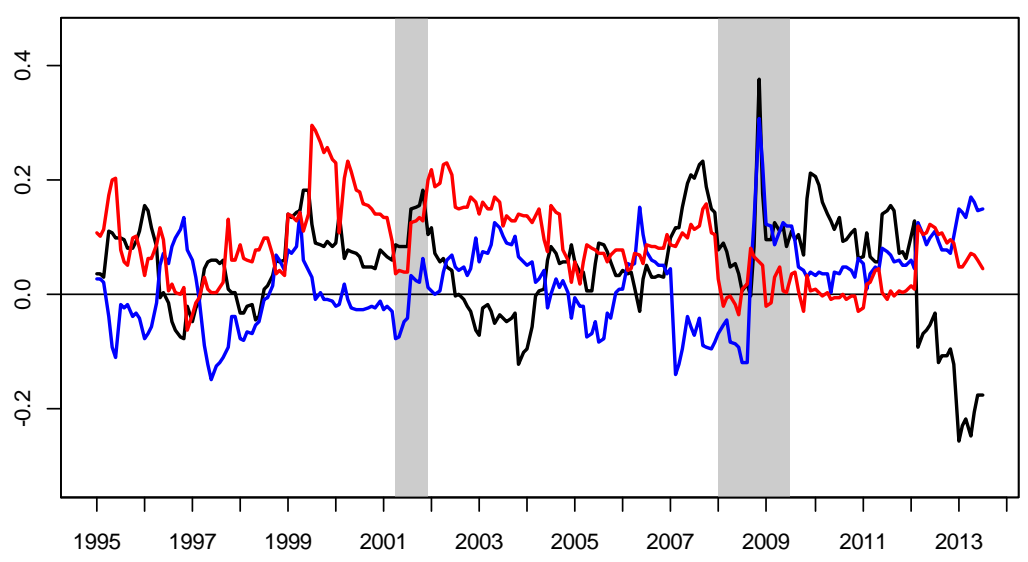

(Black=aggregate demand; Blue=Oil-market specific demand; Red=Oil supply)

\section{US Technology}

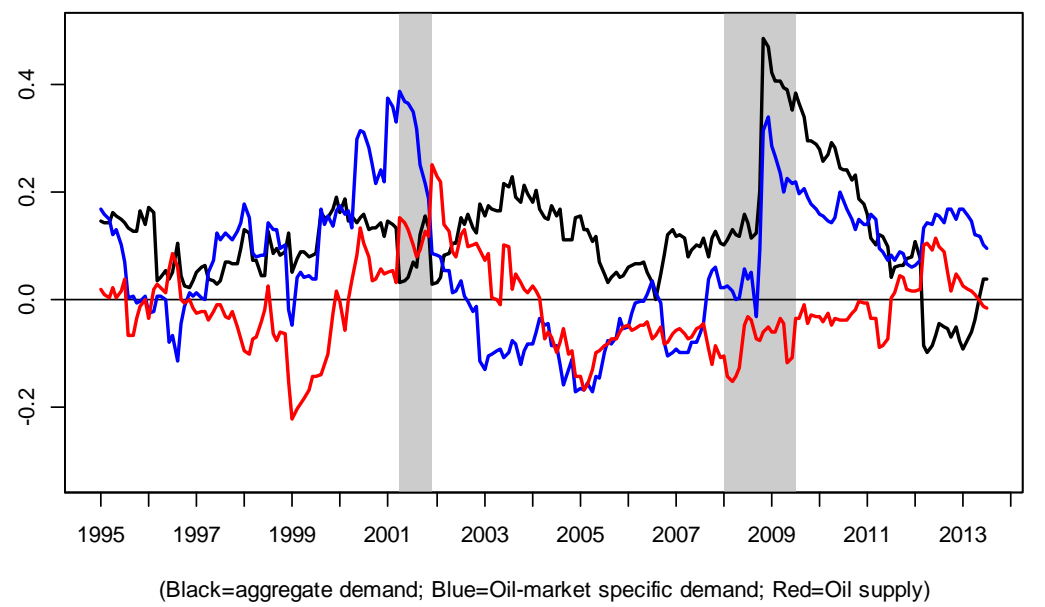

China Technology

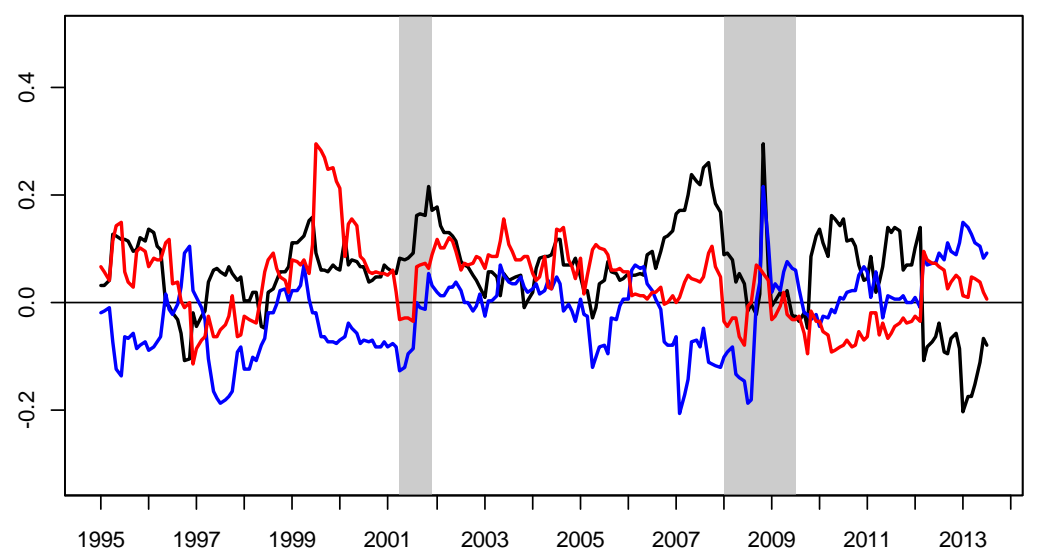

(Black=aggregate demand; Blue=Oil-market specific demand; Red=Oil supply) 
Figure 6: Time-varying correlations of Banking sector returns with oil shocks, 1995:1-2013:07.

\section{US Banks}

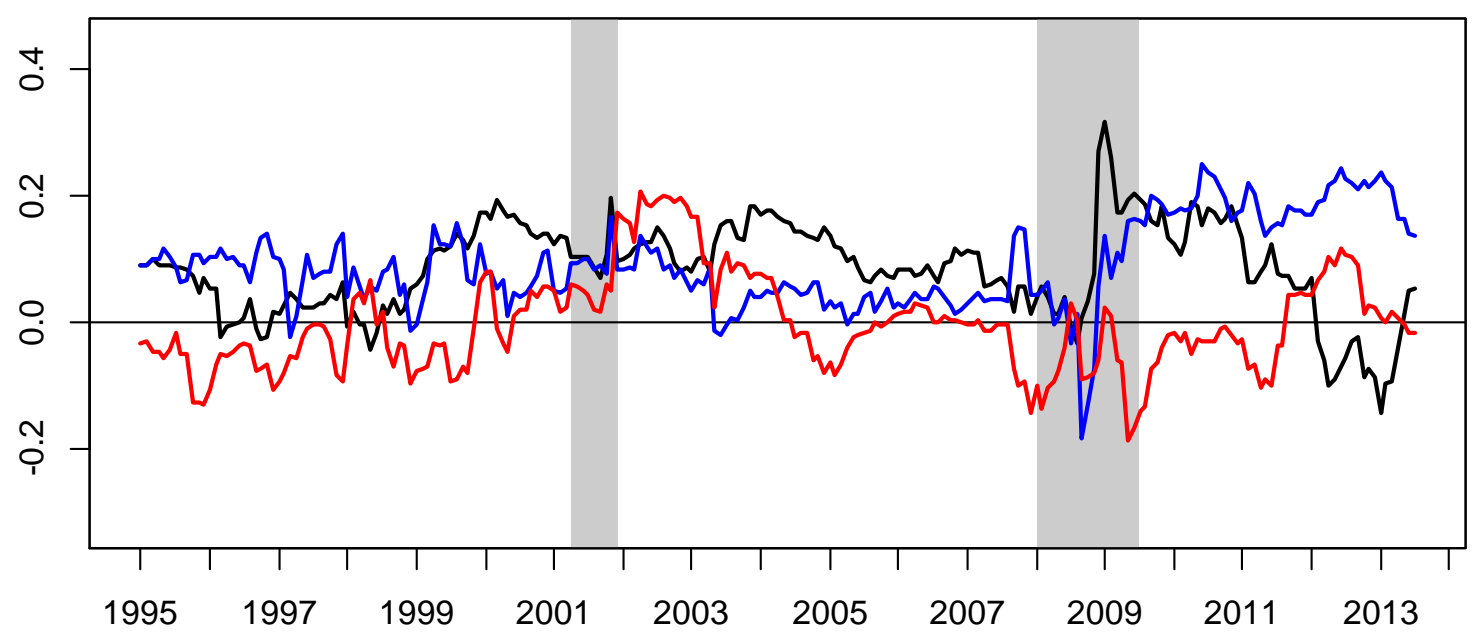

(Black=aggregate demand; Blue=Oil-market specific demand; Red=Oil supply)

\section{China Banks}

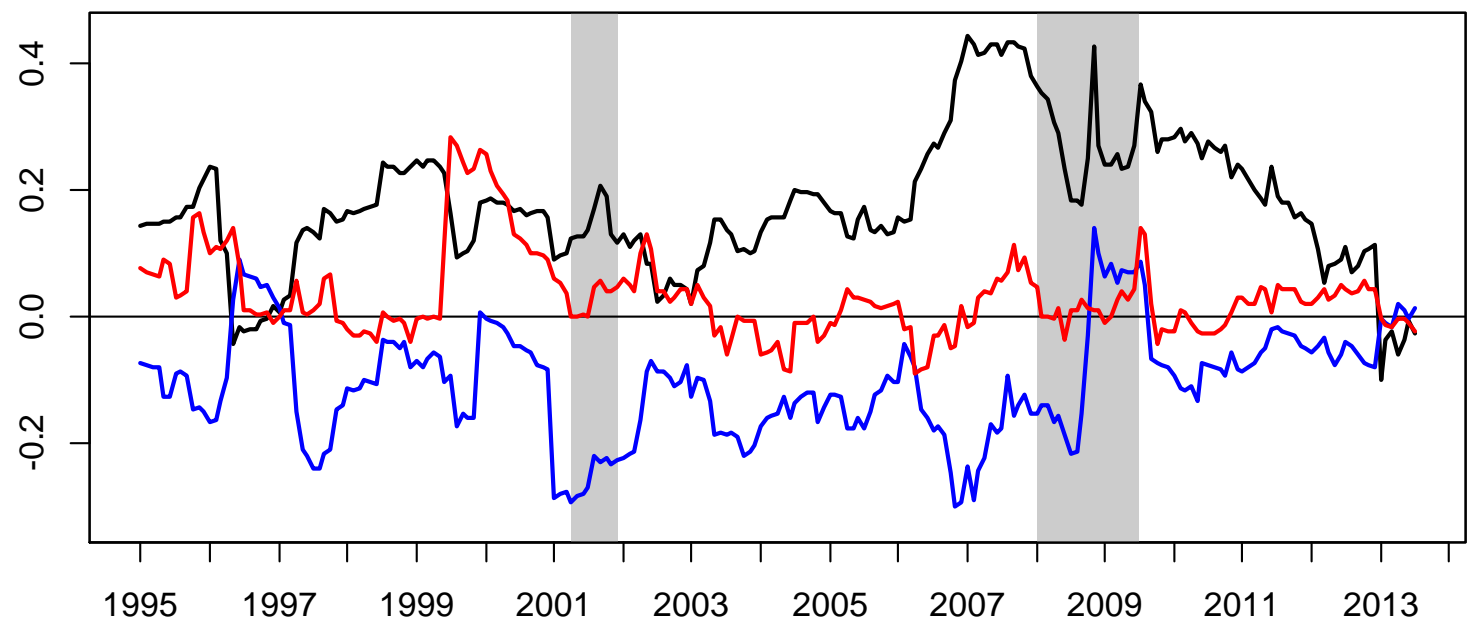

(Black=aggregate demand; Blue=Oil-market specific demand; Red=Oil supply) 